\title{
Scientific drilling of speleothems - a technical note
}

\author{
Christoph Spötl ${ }^{1}$ and David Mattey ${ }^{2}$
}

\begin{abstract}
:
Spötl C. and Mattey D. 2012. Scientific drilling of speleothems - a technical note. International Journal of Speleology, $41(1), 29-34$. Tampa, FL (USA). ISSN 0392-6672. http://dx.doi.org/10.5038/1827-806X.41.1.4

This short article provides detailed descriptions of custom-made and commercially available hand-held drilling gear and options for water-flushing units specifically designed to obtained good-quality core material from speleothems even in remote cave regions. We use small-diameter $(6-7 \mathrm{~mm})$ diamond drill-core bits to obtain aliquots of calcite (as little as a few hundred milligrams) from the interior of the basal part of in-situ stalagmites. These small cores are used to date the onset of stalagmite growth and occasionally to obtain other compositional information. Larger diameter drill-core bits produce cores 25-32 mm in diameter and up to $1.3 \mathrm{~m}$ in length which reveal internal structures and provide axial transects for chemical and isotope analysis and material for preparation of thin sections. This system has been successfully employed to sample flowstone and thick stalagmites. Given the growing interest in speleothem as archives of past environmental change, careful sample selection is primordial to keep the impact of sampling in these unique environments at a minimum. Low-invasive drilling is an essential technique and maximizes the amount of information gained.
\end{abstract}

Keywords: speleothem; flowstone; stalagmite; sampling; coring; cave conservation

Received 13 April 2011; Revised 13 May 2011; Accepted 16 May 2011

\section{INTRODUCTION}

Recent years have seen a strongly increasing interest of geoscientists in caves in general and speleothems in particular. Although it was recognized half a century ago that speleothems may provide useful palaeoenvironmental information (e.g., Broecker et al., 1960; Hendy \& Wilson, 1968) it was only during recent decades that data obtained from these deposits have gained wider acceptance in the scientific community. During the last ten years palaeoenvironmental research has boomed and speleothem studies have become popular among scientists trying to reconstruct past climate change on a range of timescales. This development was fuelled by improved analytical techniques and a number of high-impact publications demonstrating the enormous potential of stalagmites (and less commonly flowstone) as high-fidelity climate archives (e.g., Wang et al., 2001) that can be precisely dated and correlated with instrumental and proxy records.

\footnotetext{
${ }^{1}$ Institute of Geology and Palaeontology, University of Innsbruck, Innrain 52, 6020 Innsbruck, Austria.

(christoph.spoetl@uibk.ac.at)

${ }^{2}$ Department of Earth Sciences, Royal Holloway, University of London, Egham, Surrey, TW20 OEX, UK.

(mattey@es.rhul.ac.uk)
}

The surge in speleothem research has triggered a wave of interest in cave environments as it is now widely recognized that speleothem proxy data need to be understood in the context of the local cave setting to derive robust palaeoclimatic information. It is also important that that records should be replicated within a given cave system, i.e. temporally overlapping speleothems are required (e.g., Dorale \& Liu, 2009), and as a result pressure is high for scientists to obtain a series of stalagmites from a given cave. Speleothem climate proxy research necessitates that a whole stalagmite is permanently removed from the cave and to make things worse, the best suited growth forms for palaeoclimatic studies are the aesthetic, equaldiameter (candle-stick) stalagmites (e.g., Kaufmann, 2003; Fairchild et al., 2006; Dreybrodt \& Romanov, 2008). Furthermore, speleothem science relies on a measure of good luck in that the samples selected and removed are suitable for the intended analyses and scientific objectives. They might have high porosity, growth hiatuses, high abundance of detritus, or be composed of calcite that is not suitable for $U$ series dating, e.g. because of diagenetic alteration.

Caves are unique environments protected by law in most countries. Removing stalagmites always represents a serious, irreversible impact and should be carefully evaluated and coordinated with local authorities and speleologists. A way to minimise the impact on the cave environment and to avoid overcollection is to take drill cores of speleothems rather 
than removing entire formations. Whittaker (2006, in: Frappier, 2008) reported a study in which only one tenth of the stalagmites sampled in caves from New Zealand using basal coring were found to be useful for palaeoenvironmental research. The purpose of this communication is to inform on some technical aspects of how to efficiently take drill cores from speleothems which might assist other researchers to minimize the impact of their sampling on the cave environment.

\section{PREVIOUS WORK}

Scientific drilling of speleothems has been used by several groups in the past, but to our knowledge technical details have not been reported. Rock coring is a commonplace technique in areas of geoscience such as palaeomagnetism where drills are normally powered by petrol engines. Calcite is a soft material and coring can be carried out successfully using low powered electric drills. Most authors appear to have used commercially available gear powered by either batteries or mains supply (in some show caves). Rock coring requires continuous flushing of the borehole with water, but again, documentation on these procedures is scarce, particularly regarding working in cave environments.

A number of researchers employed coring in order to study flowstone (e.g., Hellstrom et al., 1998; Meyer et al., 2008; Siklósy et al., 2009) and obtained continuous cores - typically $2-3 \mathrm{~cm}$ in diameter - perpendicular to the growth stratigraphy. Others aimed at larger diameter cores and employed rather bulky gear attached to the surface of the formation using anchor bolts (e.g., Frisia et al., 1993; Häuselmann, 2002). Stalagmites have also been drilled, in particular those ones too large to be removed entirely. Brook et al. (2006) cored a large column in Carlsbad Cavern (New Mexico) horizontally and obtained a $2.8 \mathrm{~m}$-long core. Verheyden et al. (2006) obtained a $2 \mathrm{~m}$-long core from a tall stalagmite of the Han-sur-Lesse cave in Belgium which covers the last 1800 years. Yang et al. (2007) cored two large stalagmites from a cave on the Tibetan Plateau vertically and retrieved $30 \mathrm{~mm}$-diameter cores of the topmost 30 and $14 \mathrm{~cm}$, respectively, for a detailed study of the last 50 years. An innovative approach was used by Dorale et al. (1992) who removed a small stalagmite from Cold Water Cave (Iowa), cored it from the bottom up (2.5 $\mathrm{cm}$ diameter) and restored it afterwards to its original position to preserve the ornamentation of the cave. Coring was also performed in rather difficult conditions: Winograd and his team obtained drill cores from phreatic calcite by SCUBA diving in the Devils Hole vein (Nevada) (Winograd et al., 1988, 1992).

This report describes some of the equipment, techniques and options for drilling cores and minimizing environmental impact on cave environments during speleothem sampling for palaeoclimate studies, based on experience gained at Innsbruck, and at Royal Holloway in conjunction with the Gibraltar Cave Science Unit (RH-GCSU).

\section{DESCRIPTION OF THE DRILLING GEAR} Drills

The Innsbruck setup consists of two types of drillcore bits, those for obtaining $25 \mathrm{~mm}$-diameter cores up to $1.3 \mathrm{~m}$ in length and smaller ones designed for extracting cores up to $8 \mathrm{~cm}$ in length and $6-7 \mathrm{~mm}$ in diameter. Both types consist of a metal tube with a diamond-coated core bit and a water-flushing unit (see below). Both types of drill-core bits are used in connection with hand-operated, Li-battery-powered drilling machines. We currently use a Hilti TE-6A $36 \mathrm{~V}$ machine with 3.0 Ah Li-ion batteries to drive the larger diameter drill-core bits. For the small-diameter drill-core bits we use a light-weight battery drill (Hilti SF 144-A CPC 14.4 V). Because of their much smaller diameter, these bits are directly connected to the drilling machine using its boring socket.

The systems used by RH-GCSU use battery powered drills, either a consumer grade Makita $36 \mathrm{~V} \mathrm{Li-}$ ion powered drill, or a Bosch Ni-Cd powered hammerdrill, previously used by GCSU for fixing rock bolts. If a hammer drill is used for diamond coring, extreme caution must be taken not to engage the hammer action otherwise the bit and water-swivel will be quickly and severely damaged.

\section{Water flushing}

A flow of water is used during coring to flush cuttings from the hole which greatly improves the speed of cutting, the quality of core retrieval and the longevity of the drill-core bit. Water is introduced to the centre of the core bit through a water swivel adaptor, and flows between the core and the drill-core bit, past the cutting surface and exiting into the cave carrying fine grained debris from the cutting process. Water can be supplied under pressure or by gravity feed. The Innsbruck system utilizes small inexpensive water containers pressurised by pump action that are sold in garden shops with a custom-made adapter to connect the tubing which provides pressurized water (Fig. 1). The water supply is operated by a second person (requires periodic pumping to maintain a moderate pressure in the vessel) who assists the

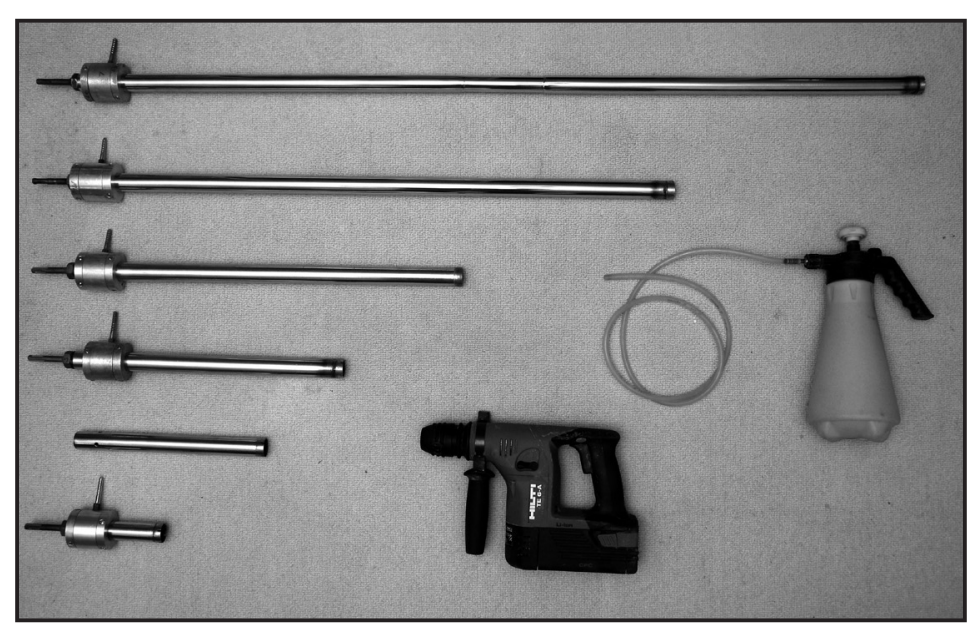

Fig. 1. Selection of $25 \mathrm{~mm}$ diameter drill-core bits (up to $1.3 \mathrm{~m}$ in length) used to core flowstone and tall stalagmites together with the drilling machine and the water supply system. On the second smallest drill-core bit the SDS adapter and the water flushing system were removed. 
drilling person and makes sure that the borehole is sufficiently flushed during drilling.

The system used by RH-GCSU is a commercial water swivel adaptor obtained from UKAM Industrial Tools, USA (http://www.ukam.com/water_swivel_adopters.html) but similar fittings are also available in the UK from Applied Diamond (Products) Ltd. (http://www.applieddiamond.com/). Water is supplied by gravity feed from flexible soft polythene containers that can be filled in the cave, emptied and packed away for transport in and out of the cave. The water container can be placed higher on rocks above the drilling site or held aloft by an assistant (Fig. 2).

The amount of water needed for a drilling operation need not be great with no more than a few litres required to cut a $50 \mathrm{~cm}$ core. The waste effluent produced by cutting is a milky water that may stain rock surfaces or contaminate pools, and additional water may be required for cleaning off these deposits (see below).

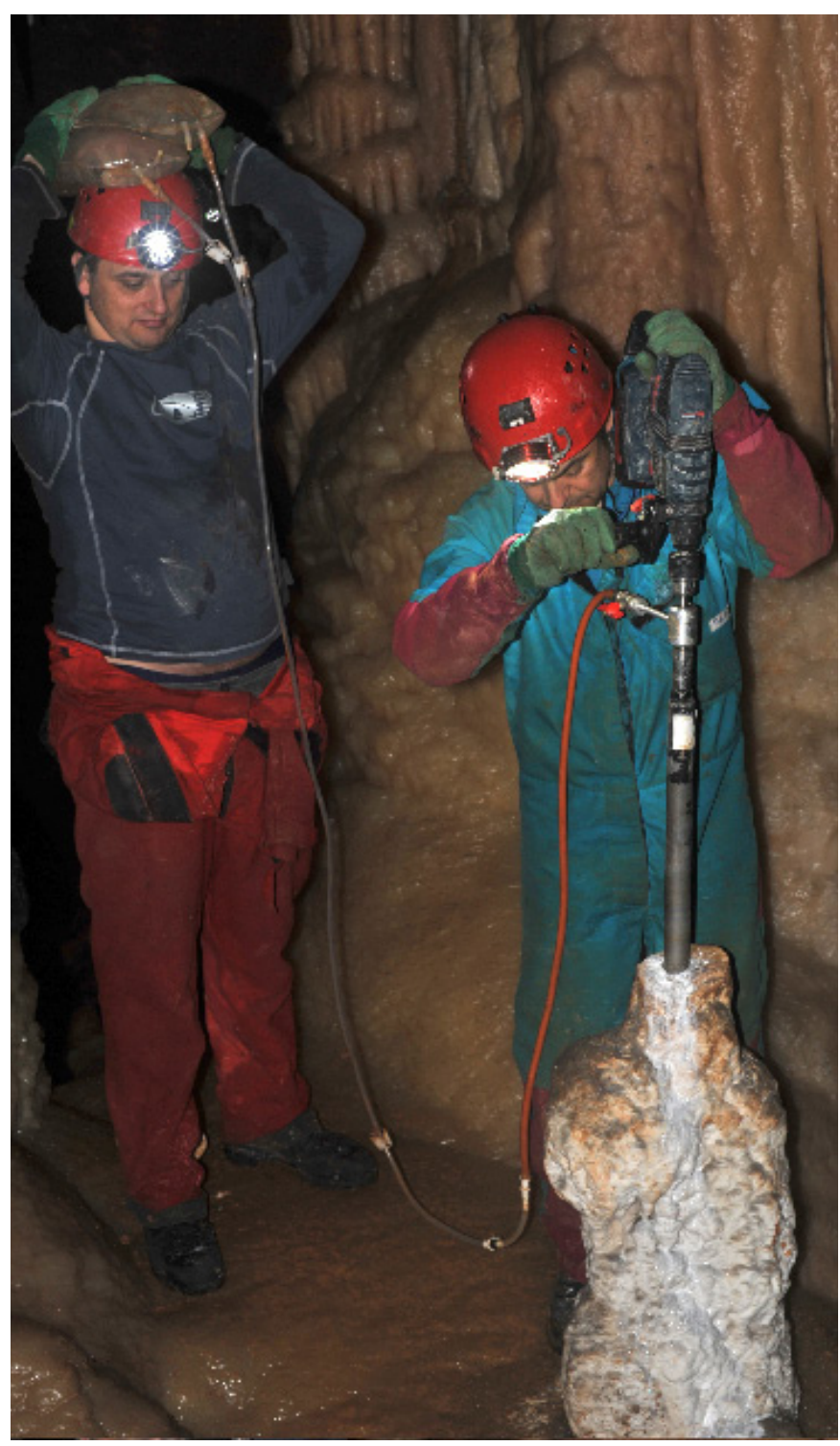

Fig. 2. Drilling into a broken stalagmite in Crystal Cave, Gibraltar using a gravity-feed water supply fed from a medical grade polythene bag to a UKAM water swivel and $38 \mathrm{~mm}$ diameter diamond coring bit powered by a Makita 36V Li-ion cordless drill.

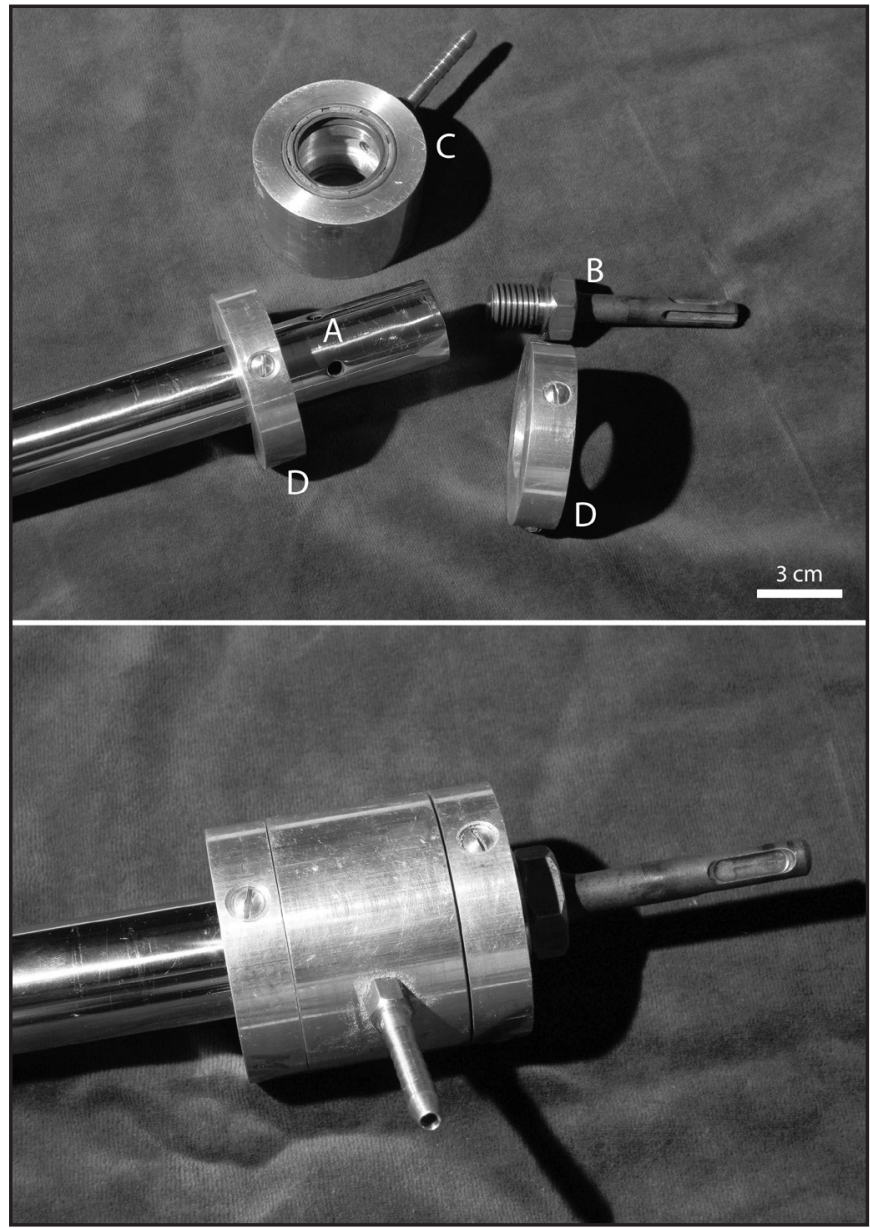

Fig. 3. Detail of Innsbruck water flushing system. Top panel dissembled system consisting of the perforated chrome-plated cylinder (A), SDS connector (B), the swivel with two radial shaft seals and the connector to the tubing $(C)$, and the two rings which hold (C) in place. Lower panel - assembled system.

\section{Drill-core bits}

The larger diameter bits used in the Innsbruck system consist of an steel tube (outer diameter 29.0 $\mathrm{mm}$, inner diameter $25 \mathrm{~mm}$ ) chrome-plated on the outside in order to prevent corrosion and minimize friction. The upper end of the tube contains the coring bit made of a bronze alloy with embedded diamonds (produced by E. Friedl \& Co, Vienna, Austria, www. diafriedl.at). The alloy is optimized for drilling of carbonates, i.e. rather soft rock. Our experience shows that slotted crowns are more efficient for coring (soft) carbonate material than unslotted crowns because of faster cutting and greater water flow. Slotter crowns, however, are more fragile and can be damaged by sideways impact. The lower end of the tube is connected to a Special Direct System (SDS) adapter via a screw thread (Fig. 3). This allows to unscrew the adapter and to open the tube from the back, which is important in case a core piece gets stuck and needs to be pushed out of the tube from behind. Given the fact that the drilling process will tighten the thread it can be quite difficult to unscrew the adapter. A hexagonal head is therefore welded to the SDS connection allowing the user to apply a wrench to unfasten the adapter (Fig. 3). The lower 


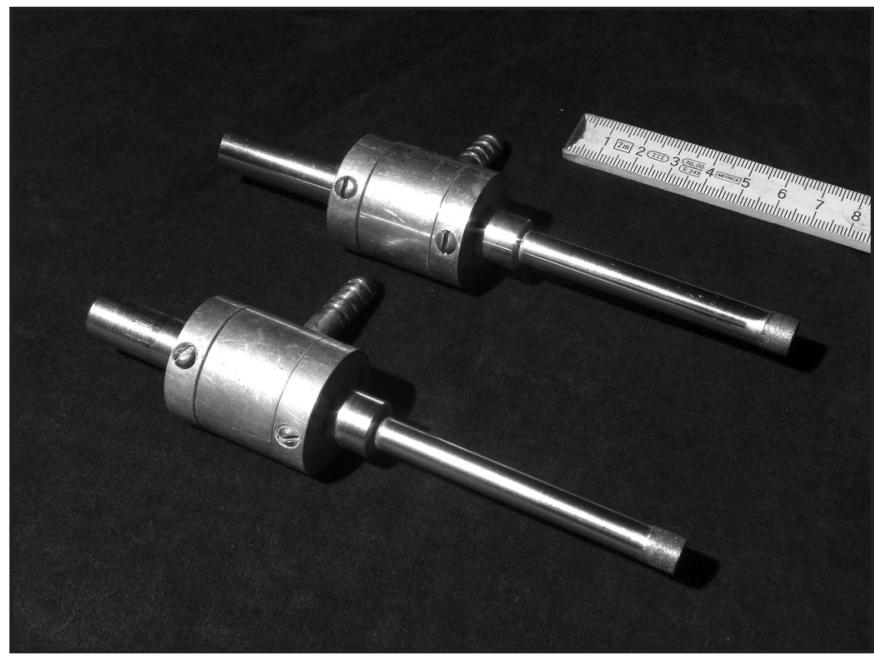

Fig. 4. Two small-diameter drilling bits (cm-scale) used to obtain cores samples (5.6-6.9 mm diameter) for reconnaissance dating of in-situ stalagmites.

part of the tube is perforated to permit flushing water to enter the interior of the tube. In order to provide continuous water supply during the drilling process an aluminum swivel sits above the perforated part held in place by two rings fixed to the tube by screws. Two radial shaft seals provide a water-tight connection between the swivel and the rotating drilling tube (Fig. 3). It is important that these seals are not too tight to cause friction.

The second type of drill-core bit is much smaller, and ranges from 5.6 to $6.9 \mathrm{~mm}$ inner diameter (7.6 to $8.5 \mathrm{~mm}$ outer diameter - Fig. 4). The steel tube is also chrome-plated and the upper end of the tube contains the diamond core bit. The lower end is closed by a (headless) screw made of brass to prevent rusting. This again allows cleaning of the tube from behind in case core pieces get stuck. The water flushing unit has a similar design to the one described for the 25 $\mathrm{mm}$-drill-core bits but is significantly smaller in size (Fig. 4).

The drill-core bits used by RH-GCSU are $38 \mathrm{~mm}$ diameter and $500 \mathrm{~mm}$ long (produced by Applied Diamond (Products) Ltd., UK, http://www.applieddiamond.com/) and are attached to the water swivel by a $1 / 2$ " British Standard Pipe (BSP) screw thread. This can also be difficult to remove after use in the field and appropriate tools are needed to change bits.

\section{Drilling and battery life}

\section{DISCUSSION}

The small-diameter drilling bits have proven very useful to sample in-situ stalagmites up to $14 \mathrm{~cm}$ in diameter. Using drill-core bits smaller than ca. $6 \mathrm{~mm}$ leads to poor recovery as the material tends to break or even disintegrate during the coring process. We commonly drill horizontally close to the stalagmite's base and use the innermost core piece (halfway into the stalagmite) to obtain a reconnaissance date of the onset of stalagmite growth (Fig. 5). Even with low $\mathrm{U}$ contents in the $0.05-0.1 \mathrm{ppm}$ range modern $\mathrm{MC}$ ICP-MS instruments are capable of determining a reasonably precise U-Th date from as little as a few tens of milligram and e.g. a $5.6 \mathrm{~mm}$-diameter core piece only $3 \mathrm{~mm}$ in length weighs already about 200 mg. Drilling takes a few minutes only and one $2.6 \mathrm{Ah}$ Li-ion battery lasts for several boreholes $7 \mathrm{~cm}$ deep.

The larger 25 to $38 \mathrm{~mm}$ bits are mostly used for coring flowstone but also tall in-situ stalagmites. Care must be taken at the beginning of the coring process when the guiding in the borehole is not yet sufficient so that even a slight twisting can lead to the breakage of the core. The longer the drilling bit to start with the more difficult it is to keep it straight. We therefore recommend drill-core bits of continuously increasing lengths which are exchanged as soon as the previous bit reached the maximum drilling depth (Fig. 1). The SDS connection proved essential to guarantee smooth, vibration-poor, concentric drilling. If the borehole is well flushed drilling a shallow borehole consumes about the same energy as a e.g. $1 \mathrm{~m}$ deep one. A Hilti 3.0 Ah Li-ion battery typically lasts for ca. $30-40 \mathrm{~cm}$, i.e. about four batteries are needed to complete a 1.3 m-deep hole. This takes roughly one hour of drilling. Drilling progress obviously varies depending on the density of the material.

Experience with the consumer grade cordless drills such as the Makita $36 \mathrm{~V}$ unit used by the RHGCSU group have been less positive as the Li-ion batteries in these units are electronically protected from overheating, and have been known to shut down after prolonged high current draw while drilling cores in a cave. Some care may be needed in selecting drill units for coring powered by Li-ion batteries, but the types designed for heavy-duty use are an excellent choice on account of their lower weight, higher power density and low charge loss. Ni-Cd batteries, however, remain a good alternative since they are rugged, have no controlling electronics and provide high current outputs without overheating. They are heavier and less convenient but otherwise yield high power and excellent performance in continuous use. Lead-acid batteries are not suitable not only because of weight and bulk, but they are not designed for deep discharge cycles and are damaged when run completely flat.

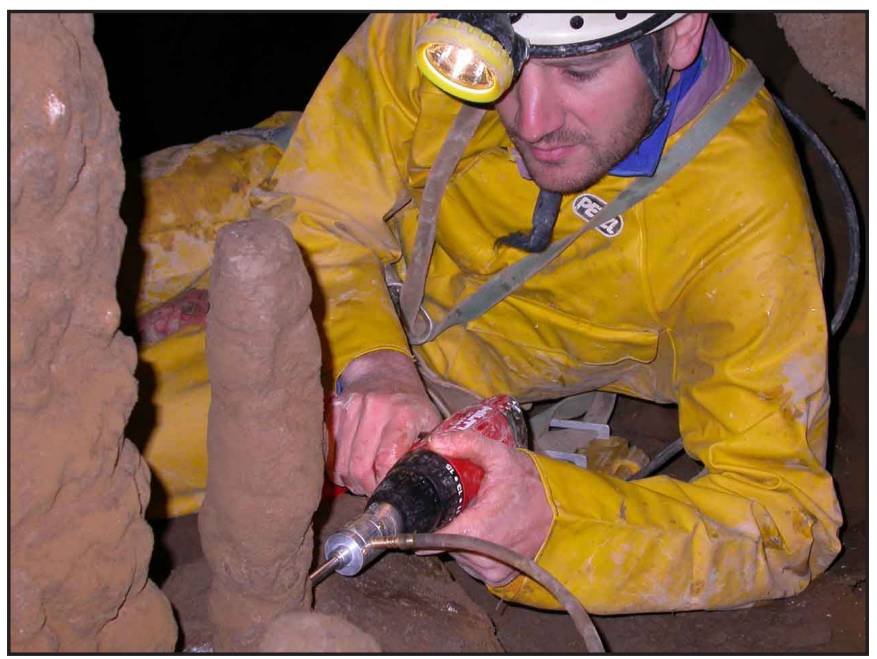

Fig. 5. A light-weight battery-powered drill is used in conjunction with a water-flushed drill to obtain small cores from the inner part of stalagmites for a rapid screening a large number of speleothems. 


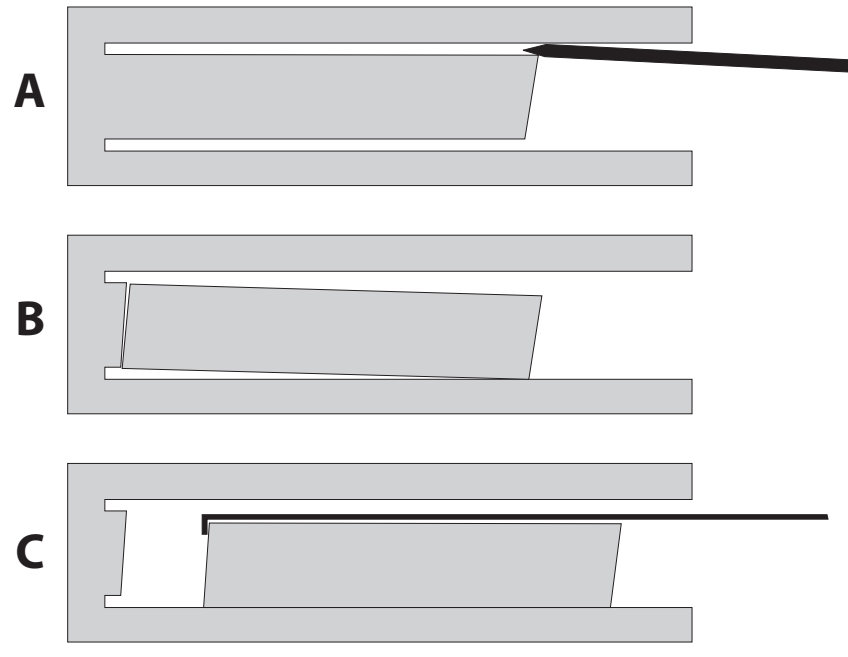

Fig. 6. Schematic drawing of the sequence of breaking and retrieving a core. A and $\mathrm{B}$ : core is broken near its base using a flattipped tool. Some cores break already by gently pushing the rod into the void between the core and the wall of the borehole, others may require a hit by a small hammer. C: Removal of the core using a thin rod with a bent end.

\section{Core recovery}

The length of core that can be recovered from drilling speleothem deposits will obviously depend on natural weaknesses but many forms of speleothem calcite, flowstone especially, are extremely tough and individual core segments ranging between 20 and 40 $\mathrm{cm}$ in length can be routinely recovered. Unless the core fractures during drilling, a tool is needed to break the core at the base of the borehole at the end of the drilling process. This can be a long, flat tipped screwdriver or the Innsbruck system uses thin metal rods of different lengths with a chisel-like flat tip and little force is usually required to break the core loose (Fig. 6). The core can be recovered in a variety of ways - the Innsbruck system uses another metal rod (e.g. welding rods) thin enough to slide between the core and the borehole and equipped with a bent tip used to fetch the core at its base and retrieve it from the borehole (Fig. 6). Another solution are long barbeque tongs made of thin metal with cylindrical tips, and another is a thin-walled aluminium tube with a slit cut along its length that can be squeezed around the core to grip it.

Drilling success not only depends on the drilling gear, the efficiency of flushing and the ability to keep straight during the first ca. $10-15 \mathrm{~cm}$, but also on the material properties of the speleothem. There is no general rule, but porous and very coarsely crystalline or sparry calcite tends to be susceptible to disintegration during drilling and core recovery can be poor. Use of larger diameter drill-core bits (e.g. $50 \mathrm{~mm}$ diameter) may be an advantage coring brittle samples but tougher compact calcite allows continuous cores of $30-40 \mathrm{~cm}$ in length to be cut using drill diameters described above. It is advisable to immediately stop the drilling as soon as the core breaks (which can be noticed with some experience by a subtle change in the behavior or sound of the drill-core bit) and to remove the core; otherwise individual core segments can rotate against each other inside the drill tube resulting in further fragmentation and loss of material at the core breaks.

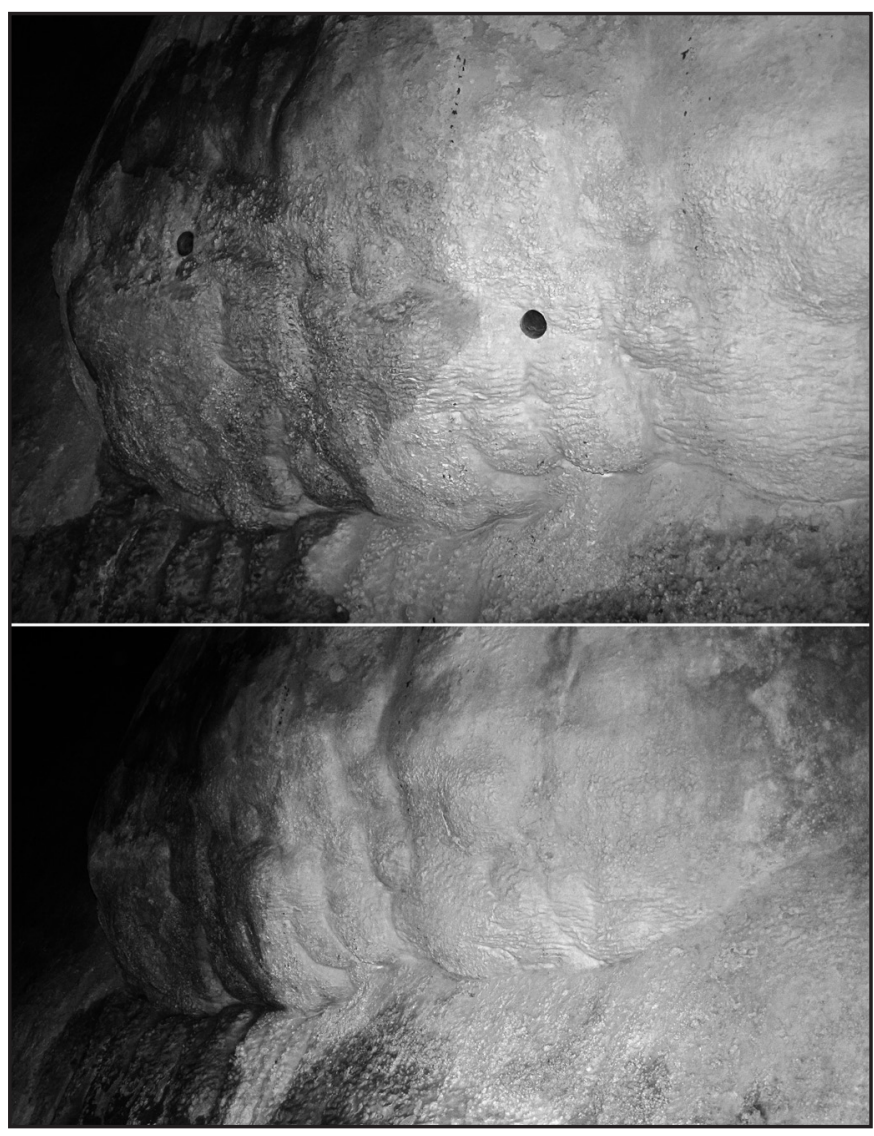

Fig. 7. Example of a speleothem cored by two drillings (top panel) and subsequent to patching the holes (lower panel). Width of images ca. $1.5 \mathrm{~m}$.

\section{Environmental impacts}

The drill holes can be filled and patched using cave loam or, more professionally, using e.g. epoxy resin or a mixture of a small quantity of Portland cement and crushed core material or cave sediment, to restore the appearance and color of the stalagmite or flowstone surface (Fig. 7). Within a short time, especially in areas of active calcite deposition there is usually little evidence of the core ever having been taken. Another consideration is the milky stream of suspended carbonate particles produced by the flushing process which will stain the cave floor and contaminate flowstone and cave pools. This can often be washed away and we had good experience with damming this fluid using towels and carefully cleaning the workplace after coring.

\section{ACKNOWLEDGEMENTS}

Our speleothem research has been funded by grants of the FWF and DFG, and in the UK by the Natural Environment Research Council. CS thanks his father Hans Spötl for his generous help in designing the water-flushing system and the team at Innsbruck University for its great support, and in particular Yuri Dublyansky and Marc Luetscher for helpful comments on a first draft of this paper. DM would like to thank drillmeister Richard Durell and members of the Gibraltar Cave Science Unit for their drilling endeavours in Gibraltar caves. Comments by two technical reviewers are acknowledged. 


\section{REFERENCES}

Broecker W.S., Olson E.A. \& Orr P.C., 1960 - Radiocarbon measurements and annual rings in cave formations. Nature, 185: 93-94. http://dx.doi.org/10.1038/185093a0

Brook G.A., Ellwood B.B., Railsback L.B. \& Cowart J.B., 2006 - A 164 ka record of environmental change in the American Southwest from a Carlsbad Cavern speleothem. Palaeogeography Palaeoclimatology Palaeoecology, 237: 483-507. http://dx.doi.org/10.1016/j.palaeo.2006.01.001

Dorale J.A. \& Liu Z., 2009 - Limitations of Hendy test criteria in judging the paleoclimatic suitability of speleothems and the need for replication. Journal of Cave and Karst Studies, 71: 73-80.

Dorale J.A., González L.A., Reagan M.K., Pickett D.A., Murrell M.T. \& Baker R.G., 1992 - A high-resolution record of Holocene climate change in speleothem calcite from Cold Water Cave, northeast Iowa. Science, 258: 1626-1630. http://dx.doi.org/10.1126/science.258.5088.1626

Dreybrodt W. \& Romanov D., 2008 - Regular stalagmites: the theory behind their shape. Acta Carsologica, 37: 175-184.

Fairchild I.J., Smith C.L., Baker A., Fuller L., Spötl C., Mattey D., McDermott F. \& E.I.M.F., 2006 - Modification and preservation of environmental signals in speleothems. Earth-Science Reviews, 75: 105-153. http://dx.doi.org/10.1016/j.earscirev.2005.08.003

Frappier A.B., 2008 - A stepwise screening system to select storm-sensitive stalagmites: Taking a targeted approach to speleothem sampling methodology. Quaternary International, 187: 25- 39. http://dx.doi.org/10.1016/j.quaint.2007.09.042

Frisia S., Bini A. \& Quinif Y., 1993 - Morphologic, crystallographic and isotopic study on an ancient flowstone (Grotta di Cunturines, Dolomites) - implications for paleoenvironmental reconstructions. Spéléochronos, 5: 3-18.

Häuselmann P., 2002 - Cave genesis and its relationship to surface processes: investigations in the Siebenhengste region (BE, Switzerland). Höhlenforschung im Gebiet Sieben Hengste- Hohgant, 6: 1-166.

Hellstrom J., McCulloch M. \& Stone J., 1998 - A detailed 31,000-year record of climate and vegetation change, from the isotope geochemistry of two New Zealand speleothems. Quaternary Research, 50: $167-178$.

http://dx.doi.org/10.1006/qres.1998.1991
Kaufmann G., 2003 - Stalagmite growth and palaeoclimate: the numerical perpective. Earth Planetary Science Letters, 214: 251-266. http://dx.doi.org/10.1016/S0012-821X(03)00369-8

Hendy C.H. \& Wilson A.T., 1968 - Palaeoclimate data from speleothems. Nature, 219: 48-51. http://dx.doi.org/10.1038/219048a0

Meyer M., Spötl C. \& Mangini A., 2008 - The demise of the Last Interglacial recorded in isotopically dated speleothems from the Alps. Quaternary Science Reviews, 27: 476-496. http://dx.doi.org/10.1016/j.quascirev.2007.11.005

Siklósy Z., Demény A., Vennemann T., Pilet S., Kramers J., Leél-Össy S., Bondár M., Shen C.- C. \& Hegner E., 2009 - Bronze Age volcanic event recorded in stalagmites by combined isotope and trace element studies. Rapid Communications in Mass Spectrometry, 23: 801-808. http://dx.doi.org/10.1002/rcm.3943

Verheyden S., Baele J.-M., Keppens E., Genty D., Cattani O., Cheng H., Edwards L., Zhang H., van Strijdonck M. \& Quinif Y., 2006 - The Proserpine stalagmite (Han-Sur-Lesse Cave, Belgium): preliminary environmental interpretation of the last 1000 years as recorded in a layered speleothem. Geologica Belgica, 9: 245-256.

Wang Y.J., Cheng H., Edwards R.L., An Z.S., Wu J.Y., Shen C.-C. \& Dorale J.A., 2001 - A high-resolution absolute-dated late Pleistocene monsoon record from Hulu Cave, China. Science, 294: 2345-2348. http://dx.doi.org/10.1126/science.1064618

Winograd I.J., Szabo B.J., Coplen T.B. \& Riggs A.C., 1988 - A 250,000-year climatic record from Great Basin vein calcite: implications for Milankovitch theory. Science, 242: 1275-1280.

http://dx.doi.org/10.1126/science.242.4883.1275

Winograd I.J., Coplen T.B., Landwehr J.M., Riggs A.C., Ludwig K.R., Szabo B.J., Kolesar P.T. \& Revesz K.M., 1992 - Continuous 500,000-year climate record from vein calcite in Devils Hole, Nevada. Science, 258: 255-260. http://dx.doi.org/10.1126/science.258.5080.255

Yang X., Zhang P., Cheng F., Huh C., Li H., Cheng H., Johnson K.R., Liu J. \& An C., 2007 - Modern stalagmite oxygen isotopic composition and its implications of climatic change from a high-elevation cave in the eastern Qinghai-Tibet Plateau over the past 50 years. Chinese Science Bulletin, 52: 1238-1247. http://dx.doi.org/10.1007/s11434-007-0166-4 